\title{
Os espelhos da alteridade em "Luisa, filha de Nica" de Orlanda Amarílis
}

\author{
Prisca Agustoni de Almeida Pereira \\ (Universidade Federal de Juiz de Fora)
}

\section{RESUMO}

Nesse artigo pretende-se analisar o conto "Luísa, filha de Nica", da escritora caboverdiana Orlanda Amarílis, a partir do referencial temático da alteridade, identificado na representação de várias personagens do referido conto. A maneira como é trabalhado o outro - o louco, o possuído, o morto - nos revelam uma visão de mundo que não se encaixa nos padrões racionais de sociedades oriundas do Iluminismo.

PALAVRAS-CHAVE: identidade; alteridade; ficção africana contemporânea

\section{RESUMEN}

En este artículo se analiza el cuento "Luísa, filha de Nica", de la escritora de Cabo Verde Orlanda Amarílis, desde el referencial temático de la alteridad, identificado en la representación de distintos personajes del cuento. El modo como se trabaja a la figura del otro - sea el loco, el poseído, el muerto - nos muestra una visión del mundo que no se encaja en los moldes racionales de las sociedades oriundas del Iluminismo.

PALABRAS CLAVE: identidad; alteridad; ficción africana contemporánea 
Nosso trabalho pretende analisar um conto da escritora cabo-verdiana Orlanda Amarílis, mas, pela temática aqui enfocada, é possível aproximá-lo a vários outros contos africanos de língua oficial portuguesa nos quais existe uma personagem considerada "deslocada" pelo narrador, pela recepção do leitor ou pelas "outras" vozes que afloram no conto. Com evidência, ao longo de nossa análise, serão chamados em causa outros temas, a este relacionado, que dizem respeito à representação e à decodificação do mundo africano contemporâneo por parte da escritora, assim como será abordada a relação fundamental entre tradição oral africana - reserva de histórias, contos, lendas e assombrações - e a tarefa do escritor, que tenta, muitas vezes, "traduzir" ou ficcionalizar em língua nacional oficial muitas dessas histórias ouvidas e recolhidas na berma das muitas estradas da terra africana. Estradas de terra, estradas de sabedoria e de imaginação, que criam o maravilhoso e o cotidiano, o susto e a ternura presentes de maneira tão peculiar nos contos africanos contemporâneos abordados neste trabalho.

O conto que abordaremos é "Luísa filha de Nica" de Orlanda Amarílis ${ }^{1}$. Antes, é preciso esclarecer que se decidimos privilegiar esse enfoque é porque acreditamos que este conto tem elementos recorrentes na ficcão africana contemporânea, qual sejam a elaboração duma realidade (ficcional) questionada pelo surgimento ameaçador da "alteridade", categoria cujas características são encarnadas por personagens que se situam à margem da sociedade, à margem da fala, à margem da ordem estabelecida por um padrão de comportamento que envolve um grupo definidor da "identidade". Trata-se, à primeira vista, de personagens como Luísa, a filha de Nica (no conto de Orlanda Amarílis), mas também, por exemplo, de Kilausse, menino-personagem presente no conto "Gavião veio do sul e pum!" , do escritor angolano Boaventura Cardoso, ou também da menina "há-de-se-ver" no conto "Na berma de nenhuma estrada", de Mia Couto. Contudo, nossa análise tenta mostrar como outras personagens que rodeiam essas figuras chamadas de "deslocadas" também poderiam ser entendidas da mesma forma (por nós leitores, pela sociedade ou pelos próprios "deslocados") a saber, como "malucos [...] de cabeça avariada" (Cardoso, 1980, p. 40).

Do ponto de vista sociológico, a relação entre o grupo (os sujeitos) e o "outro" (o não-sujeito) é marcada pela tensão, uma vez que os sujeitos são os que observam e avaliam o grau de "diferença" do outro, estabelecendo socialmente o conceito de "alteridade". Conforme explicam Pereira \& Gomes (2002, p. 92) ao falar do mito do Lobisomem ou da Mula-sem-cabeça no contexto brasileiro, o sentido dessas figuras postas à margem da sociedade "decorre de sua inserção num mundo tradicional, vez ou outra, perturbado pela provocação advinda do contato com diferentes grupos, espaços e temporalidades". Vale ressaltar que esse aspecto é fundamental para entender as diferentes formas de "estranheza" ou alteridade encontradas nos três contos mencionados, já que em todos esses casos estamos lidando com a realidade rural africana, sede onde a cultura popular se mantém mais vigorosa, embora esse dado não seja imprescindível para entendermos as possíveis significações do texto que, como veremos, transcendem as coordenadas da localização espaço-temporal circunstancial. De fato, a exploração literária do tema da "loucura" ou da estranheza - ou como quer que se chame esse fenômeno ${ }^{2}$ - não é novidade: personagens consideradas "deslocadas" aparecem na literatura desde sempre, desde o Dom Quixote passando por Quincas Borba, para citar apenas alguns nomes mais próximos.

No entanto, esse processo de encenação na literatura de figuras "deslocadas" parece intensificar-se ou tornar-se mais visível no caso da literatura 
que se inspira no contexto popular onde, no dia-a-dia, dão-se a ver explicitamente as relações (hierarquizadas ou menos) entre o indivíduo e a sociedade, entre o Eu e o Outro, entre um padrão de identidade aceito pela comunidade e a dissonante alteridade. Na cultura popular, a presença do "estranho", do "louco" como a personagem "Sorôco" da narrativa roseana ${ }^{3}$, é lugar comum, pois essa figura representa um dos elementos que se encaixam no mosaico da sua configuração social e simbólica, atuando dinamicamente nela. Muitas vezes, essa figura é considerada ameaçadora, horrível, por questionar através dos seus atos e de suas palavras a chamada "verdade oficial", perturbando a linearidade da experiência do grupo e chamando a atenção para a necessidade humana do confronto (com novas dimensões da realidade) e da reavaliação de ideias pré-concebidas. Ao mesmo tempo, vale lembrar que no seu estudo sobre o estranho, Freud (1976, p.292) apontou como uma das suas características principais o fato de ser "aquela categoria do assustador que remete ao que é conhecido, de velho, e há muito familiar". Porém, realizando um apanhado de verbetes que têm o mesmo significado da palavra estranho em vários idiomas, Freud chega à conclusão que, de acordo com o alemão unheimlich, identifica o estranho como aquilo que não é íntimo, que não é amigavelmente confortável e que é misterioso, por isso capaz de gerar medo.

A cultura popular, como apontam Pereira \& Gomes, está permeada por essas figuras "assustadoras", sejam elas reais ou "imaginárias", como no caso já citado do mito da Mula-sem-cabeça. Figuras essas que costumam aflorar de maneira assombrosa na linguagem, evocadas pelo poder da fala e da oralidade, na performance do contador de histórias. De acordo com o comentário de Célia Magalhães em seu estudo sobre os monstros (2003, p.14), "essa cultura predominantemente oral, povoada de monstros, teve, nos séculos da colonização, o seu momento de embate com a chamada cultura erudita, antes de tudo, literária e cristianizada. O diabo, então, infiltrou-se no nosso reino de monstros". Além disso, ao se referir à descrição dos monstros presentes nos documentos dos europeus sobre o Novo Mundo, Célia Magalhães, remetendo a Miguel Rojas Mix, esclarece que

eles faziam parte de um imaginário, que inclui o fantástico medieval e o fantástico clássico, transposto para a América. O autor comenta que a noção de 'monstro' é usada como referência a todo ser que morfológica ou culturalmente se distinga das normas estéticas ou éticas vigentes (Magalhães, 2003, p.25)

Retornaremos mais tarde à questão do fantástico como gênero literário dentro do qual a monstruosidade se impõe como construção narrativa.

Contudo, é interessante voltarmos a Freud para ressaltar a pluralidade das concepções relativas à categoria do "estranho" levantadas, dentre as quais destacamos as duas que mais interessam para nossa análise. Por um lado, chamanos a atenção a concepção do estranho como sendo o conhecido, o familiar que se torna assustador, sinistro, por algum aspecto que não se consegue abordar; nessa direção, Freud resume dizendo que "o estranho [pode ser] algo que é secretamente familiar, que foi submetido à repressão e depois voltou". Essa volta estaria relacionada à ideia do duplo (identificado agora com um objeto de terror), da repetição, ou encontraria uma das suas manifestações explícitas e "estranhas" no fenômeno da possessão, que encena a luta empreendida por uma "entidade" para 
possuir o ser humano e anular sua personalidade - seu ego -, revelando assim uma tensão ontológica entre a concepção da unidade que fundamenta a essência humana (o ego) e a existência potencial do seu duplo "misterioso". Por outra parte, destaca-se a concepção do estranho como sendo "o estrangeiro", de acordo com a sua acepção na língua grega. Nesse sentido, é interessante observar como as narrativas da cultura popular - e, por conseguinte, a literatura que se inspira no imaginário popular -

nos leva[m] a pensar sobre os discursos e os valores que os sujeitos empregam para delinear o seu estar-no-mundo, por exemplo, através da elaboração de parâmetros que delimitem as noções de familiar e estrangeiro, Eu e Outro nas relações intergrupais e interpessoais (Pereira \& Gomes, 2002, p. 94).

Vale observar, nesse ponto, que a marginalidade não é reservada unicamente aos loucos, mas também àquelas figuras "ilhadas em seus limites" (Pereira \& Gomes, 2002, p. 92) que não representam o cânone auspiciado como identidade para uma sociedade ${ }^{4}$ : nesse caso, se incluem mulheres, crianças, idosos, adolescentes. Para demarcar o limite entre o aceitável, o "normal", e a "diferença", a sociedade serve-se sutilmente de varias estratégias discursivas e simbólicas, uma das quais é a estigmatização do corpo do "outro" como sendo o locus da impureza, da natureza "selvagem", do descontrole, da bybris. Não é casual o fato de que essas figuras à margem também são chamadas de "híbridas", por estarem transitando num entre-lugar, isto é, entre a "identidade" (que eles se atribuem) e a "alteridade" (que os outros lhes apontam). Nesse sentido, nem sempre a alteridade é determinada pela marginalidade explícita, visível, justificada "cientificamente" (como o diagnóstico da loucura, a "inferioridade" da raça negra durante o século XIX, etc), mas se impõe tacitamente no grupo pelo fato de determinada pessoa atuar de forma estranha aos olhos dos sujeitos centrados na imagem do Eu, forjadora da identidade.

Voltamos, novamente, às observações de Pereira \& Gomes (2002, p. 93), ao destacarem o fato de que "a alteridade é uma questão que está além das fronteiras do grupo e no caso de manifestar-se em seu interior, é solucionada através de um mecanismo de expurgo", isto é, por meio de uma justificativa "transcendental" (religiosa ou artística) que permite a reintegração - apropriação do "outro" por parte da comunidade: trata-se, pois, de uma forma de alívio para poder aceitar o Outro no seio da comunidade. É o que acontece, por exemplo, com o mito da Mula-sem-cabeça, que se tornou patrimônio cultural brasileiro, servindo de exemplo de moralidade para vigiar a manutenção da ordem. É o que acontece, também, com o artista Artur Bispo do Rosário, "recuperado" pela sociedade brasileira enquanto artista, apesar de ter tido uma trajetória de vida "estranha", já que viveu parte da vida internado num manicômio, onde continuou a criar.

Em vista disso, podemos perguntar-nos em que medida figuras como os loucos, os que são "outros", os monstros, são o resultado de uma construção social que responde a uma necessidade de expulsar aquilo que nos enfrenta, nos questiona, nos deixa desassossegados, como coloca Jeffrey Cohen: 
Os monstros [...] podem ser expulsos para as mais distantes margens da geografia e do discurso, escondidos nas margens do mundo e dos proibidos recantos da nossa mente, mas eles sempre retornam. E quando eles regressam, [...] nos perguntam como percebemos o mundo e nos interpelam sobre como temos representado mal aquilo que tentamos situar. Eles nos pedem para reavaliarmos nossos pressupostos culturais sobre raça, gênero, sexualidade e nossa percepção da diferença, nossa tolerância relativamente à sua expressão. Eles nos perguntam por que os criamos. (Cohen, 2000, p. 23)

A problemática referida até agora, isto é, a oposição entre "normalidade" e "alteridade" está presente nos contos africanos aqui considerados, assim como a pergunta que se esconde atrás da aparente "diferença" de suas personagens centrais. De fato essas personagens deixam uma pergunta como legado para o leitor: por que nos criaram?

O conto de Orlanda Amarílis introduz-nos no interior da organização social da vida coletiva de Cabo Verde, marcada como um contexto popular. Podemos observar, desde o título, a organização desse universo, estruturado a partir das relações ligadas à vida de grupo, já que Luísa se define em função do fato de ser "filha de Nica": o eu é definido em relação ao grupo. Além disso, através do emprego da linguagem coloquial, a autora expõe os tabus da cultura popular, que vão se definindo nas palavras de Luísa (a personagem "alterada" do conto), tal como a interdição de pronunciar o nome das doenças (Amarílis, s/d, p. 31). De acordo com o contexto popular e rural no qual se situa o enredo do conto, a natureza aparece como um elemento que possui força própria, capaz de desafiar o ser humano que apenas pode aprender a lê-la, em vez de dominá-la (Amarílis, s/d, p. 34).

As personagens do conto se movem nesse universo. Apesar de a narrativa não fornecer marcas nítidas do processo de mutação que a personagem de Luísa está vivendo - o leitor se deparará com essa mudança a partir da página 37 do conto, até o desfecho -, aparecem desde o início sinais desse processo, pois o narrador se refere a ela dizendo que "parecia transtornada" (p. 31), e, logo depois, que ela "descaiu numa mansidão sem explicação"(p. 32, grifo nosso). Começa aqui a perfilar-se a suspeita de que algo "estranho" está acontecendo com Luísa, suspeita que se torna mais forte ao longo da trajetória da personagem que, desde a sua casa, percorre um longo caminho a pé em direção ao hospital, supostamente para acompanhar o tio doente. De fato, esse longo caminho lembra o percurso dos heróis míticos, que atravessam um espaço imaginário, transcendente. Ao longo do passeio, Luísa vai adentrando mais e mais no espaço da sua imaginação, do seu eu interior, à medida que o espaço exterior revela o ambiente cabo-verdiano, com sua solidão e secura. Esse espaço interior parece uma janela aberta sobre uma realidade transcendente, vasta e misteriosa, barroca na medida em que se relaciona com o contexto carnavalesco. Nessa direção, é significativa a repetida introspecção de Luísa em relação aos cuidados com o vestido de carnaval, introspecção que opera um corte nítido com a realidade "objetiva" e exterior ao seu pensamento: 
já sei onde vou pedir umas meias brancas[...] Vou-me mascarar de arlequim mercano. Chapéu alto, casaca de cetim preto sem mangas, short aos quadrados preto e branco, peitilho plissado de organdi branco, meias brancas, sapatos rasos pretos, uma bengala. E luvas brancas. Não, vou dar outro nome ao meu disfarce. Ah, já sei. Vai ser, preto quando tem vintém (Amarílis, s/d, p.34)

Logo depois, o limiar entre os dois espaços faz-se mais deslizante, provocando superposições que apontam para a ideia da confusão mental da personagem: "Luísa contava os passos [de Anton]. Sete, oito, ainda tenho que coser os quadrados de cetim branco sobre o short. E comprar borato para espalhar na sala do baile" (Amarílis, s/d, p.35). O momento é delicado, quase trágico, mas Luísa pensa no disfarce do carnaval. Ao nosso ver, isso não deixa de ser sintomático de uma cumplicidade do autor com o seu leitor relativo à personagem, já que a festa e a tragédia representam, muitas vezes, as duas faces da mesma moeda. O carnaval assume esse sentido ambivalente, de alívio e de exorcismo. No entanto, é significativa a maneira como Luísa "brinca de ser outra", brinca de ter um disfarce, ela que, de fato, no conto se revelará "outra". O contexto do carnaval impregna todas as páginas do conto, não apenas porque Luísa pensa em se disfarçar de arlequim, cujo espírito é jocoso, para assumir a aparência do negro rico ("preto quando tem vintém"), mas também porque o próprio conto foi escrito durante o Carnaval de 1977, como indica a nota final da autora. $\mathrm{O}$ disfarce de arlequim remete à ideia da máscara ou do duplo que, como vimos na introdução, é uma das ocorrências que sugerem a sensação do estranho. Este é um caso de duplo jocoso, contrastando com o duplo trágico que encontraremos mais adiante. Vale observar que a peregrinação de Luísa entre "este mundo" e o "outro mundo" é demarcada pela oposição, no conto, entre as metáforas da abertura e a do fechamento: portas, janelas, gretas, olhares, tudo está num movimento de abrir-fechar que imprime uma sensação de rarefação e claustrofobia à narração ${ }^{5}$.

Retomando a sucessão cronológica do conto, podemos observar que, a partir do momento em que Luísa cruza com Nha Ninha (Amarílis, s/d, p.34), a "deslocada da cabeça" (Amarílis, s/d, p.35), o conto começa a tomar outro rumo, até chegar ao momento em que, na página 37, tem-se a impressão de que outro conto se superpõe ao que estávamos lendo. Em realidade, o que acontece é uma inversão dos papéis, pois Nha Ninha, tida como louca pela comunidade, vai revelar a loucura de Luísa, ou pelo menos, vai desvelar o fato de que Luísa está a andar sozinha, sem a suposta companhia do tio Anton. A louca passa a questionar a linearidade do conto e da nossa experiência como leitores. Tem-se a impressão de que a loucura da primeira se transpôs para a segunda que, para nós leitores, depois desse encontro, não voltará a ser a mesma. No entanto, é interessante observar como a própria Luísa se serve da estigmatização do corpo de Nha Ninha para comprovar a "diferença" da velha. Vejamos esse fragmento: "Antes de prosseguir Luísa franziu o nariz e torceu a boca. 'Bocê anda com um cheirinho morrinhento, Nha Ninha. É de andar por aí a roçar pelo chão. Bocê é gentegrande, bem podia ter mais juízo. E se bocê fosse mudar de roupa de baixo?" (Amarílis, s/d, p. 35). Vale sublinhar, à luz do que já dissemos, o paradoxo de encontrarmos a recomendação para se ter mais juízo fixada justamente nas palavras de uma personagem que vai revelar uma progressiva perda dos referenciais racionais. Nesse sentido, acontece nesse encontro uma superposição 
de "pontos de vista" sobre a realidade, onde cada ponto de vista pertence a uma figura "estranha". Primeiro Luísa, como vimos, e depois a própria Nha Ninha emitem juízos de valor colocando o interlocutor na posição do "outro", do "diferente", do "louco":

"Ocê está encostada na parede de uma maneira. Parece como menina-de-vida".

A mão de Anton tornou-se leve no seu braço. Luísa sentiu-se livre para apontar com o dedo para a velha:

"Eles dzê que bocê é deslocada da cabeça. Que bocê é escloca. Mas quando quer insultar gente-home ou gente-mulher já não é escloca, n'é devera?".

Nha Ninha deu um risinho baixo como um sininho. "Inton, sou leve de cabeça, n’é? Inton, se uma criatura de Deus encosta sozinha como ocê, assim na parede, é ou não menina-de-vida? Logo pela manhã encostada na parede, ah gente, ou ocê é frouxinha de cabeça ou então é menina-de-vida. Ou não?” (Amarílis, s/d, p. 35)

Podemos observar, a partir desse fragmento, que a lógica e a percepção de mundo de Nha Ninha se sustentam e isso lança definitivamente sobre Luísa a representação de "pessoa estranha". O efeito provocado pela troca entre as duas personagens é ressaltado pelo narrador que, nesta circunstância, interfere de forma explícita para sublinhar a estranheza daquilo que está acontecendo: "Oh coisa estranha". A expressão de surpresa do narrador (que está aqui na posição do observador) inaugura a irrupção, agora explícita, do inexplicável, do maravilhoso, do estranho, e marca, para nós, uma quebra radical no conto que, a partir desse momento, parece explodir em imagens e frases que se juntam num vórtice, como se estivéssemos perto do começo do mundo. O próprio universo no qual Luísa se move agora é ele mesmo "estranho", assombroso, sem referentes espaçotemporais "objetivos": "Andou, andou. Cortou por vielas e caminhos [à procura de Anton]. Já não era Mindelo a sua terra" (Amarílis, s/d, p. 38). Luísa parece ter mergulhado (definitivamente?) nos meandros do seu mundo interior e não acredita naquilo que ocorre no mundo "real", ou seja, o sumiço do tio Anton. Ela comenta consigo mesma: "Credo, esta coisa é obra de feitiçaria. Nem cabe na minha cabeça. Ou estou avariada?”.( Amarílis, s/d, p. 39). Diante desta pergunta, tão angustiante para o leitor que já conhece o final do conto, resta-nos apenas comentar que este envereda para um "jardim dos caminhos que se bifurcam”, como diria Jorge Luis Borges ao falar do contexto labiríntico no qual estamos colocados e que imita os labirintos interiores da alma humana, os prováveis labirintos que perpassam a personalidade de Luísa.

Diante disso, a vOz narrativa sofre pela movimentação e participa na criação do sentimento de estranhamento: de fato, ela entra na consciência das personagens (ora de Luísa, ora de Tatóia) provocando o desdobramento do eu, portador da mensagem da sua alteridade, remetendo novamente à ideia do duplo. Contudo, esse duplo assume no presente uma conotação trágica, sendo a própria marca da volta daquilo que outrora foi reprimido e agora ameaça, causa terror, "transforma-se em estranho anunciador da morte" (Freud, 1976, p. 294). Esse duplo opera de forma autoritária, invadindo a consciência da personagem e anulando sua vontade: "O bom filho à casa torna, pensou. Ouves Luísa? Eu-Luísa, 
tu-Luísa, deixa as gargalhadas pródigas e despacha-te. Despacho-me. Eu-tu Luísa vamos. Vai e entra. Luísa correu, correu" (Amarílis, s/d, p. 40); "Ah minha ansiedade de saber. Tatóia tem calma, tem paciência. Não estejas assim a levantar e a descer teu peito raso [...] Despacha-te, Totóia, vai para casa” (Amarílis, s/d, p. 43).

Não deixa de ser significativo o fato de que o conto apresenta "coisas estranhas": a doença de Luísa é definida como "uma coisa diferente, não é doença pâ doutor" (Amarílis, s/d, p. 43). Por outro lado, Luísa "vinha dizendo umas conversas estranhas" (Amarílis, s/d, p.43), falando com o tio Anton, falecido antes de Luísa nascer. Isso nos levaria a pensar que Luísa estaria vivendo o fenômeno da possessão de um espírito que voltou e se encarnou nela. Considerando as observações de Freud sobre o papel do fenômeno da possessão no que diz respeito à manifestação daquilo que é sinistro, assustador, estranho no ser humano, torna-se mais clara a segunda parte do conto, na medida em que estaríamos lidando com um mundo atravessado por espíritos se relacionando com seres humanos, e do qual Luísa seria o limiar, o médium, o "arlequim". Tatóia, no final do conto, percebe que a estranheza de Luísa tem que ver com "coisas de intentação", com "conversa de espíritos, [...], de morto-vivo, de avassalamento" (Amarílis, s/d, p. 43). O corpo de Luísa, corpo da "alteridade" que concentra a impureza, justifica a necessidade de "fazer limpeza psíquica" (Amarílis, s/d, p. 44), ritual que dissiparia os "maus elementos" que tomaram conta da casa de Nica desde o retorno da filha.

No entanto, outra questão ainda perturba a nossa leitura: se Nha Ninha e Luísa representam a categoria da "alteridade" em relação ao grupo, o que dizer da mãe de Luísa e de Tatóia? Será que essas duas mulheres não apresentam estranhamentos?

Pois bem, ao delinearmos os perfis psicológicos dessas duas mulheres, descobrimos que elas têm tudo para engrossar a mesma categoria da "alteridade". Dito de outra forma, Nica também padece transformações que fazem dela um sujeito familiar, porém outro, desdobrado. Isso acontece primeiramente na página 32: Nica não era Nica. Era um autômato atrás da filha a tentar explicar-lhe, mas Luísa não a deixava falar. "Credo Luísa", conseguiu articular, a língua entaramelada. Parecia uma terceira pessoa em cena” (Amarílis, s/d, p. 32).

Retomando novamente as observações freudianas, reparamos que o autômato também desperta sentimentos de estranheza, pois remete a uma incerteza intelectual na apreensão do objeto inanimado excessivamente parecido com um objeto animado. Nesse sentido, Nica se torna, por momentos, dupla, ou melhor, "uma terceira pessoa em cena". Outros sinais dessa transformação ocorrem no que diz respeito às reações instintivas do corpo: "a língua entaramelada" (Amarílis, s/d, p. 32); "começou daí a esfregar a cara com as duas mãos. Esfregou, esfregou, bô dzê queria tirar a pele do rosto de tanto esfregar" (Amarílis, s/d, p. 32); "Nica entrou em pânico. Tremia sem parar" (Amarílis, s/d, p. 42). Paralelamente à progressiva perda de controle sobre o seu corpo, instaurase a progressiva perda de controle sobre a capacidade de raciocinar de forma objetiva, abrindo espaço para a confusão mental: "Nica não sabe a conta das noites em branco à cabeceira da filha. E ela sem acordar. Dez, vinte anos, cem anos? Nica perdeu-lhes a conta" (Amarílis, s/d, p.41); "Quando ela apareceu caída na porta da entrada, dias-há vinha dizendo umas conversas estranhas. Às duas por três eu também já estava enrodilhada na conversa. Eu sabia ser tudo invenção, mas ia na conversa" (Amarílis, s/d, p.43). 
Confirma-se assim a transposição dos sintomas da "alteridade" para Nica, através da convivência com a filha "frouxinha de cabeça" (Amarílis, s/d, p.37). É interessante destacar como o diagnóstico da loucura é sempre dado por uma terceira pessoa, exterior, seja no caso da Nha Ninha, seja no caso de Luísa, seja no caso de Nica, quando Tatóia lhe diz: "Tens de fazer limpeza psíquica senão bocês tudo li dentro vão ficar doidas varridas" (Amarílis, s/d, p. 44). Por outra parte, Tatóia também apresenta características que poderiam ser interpretadas como "estranhas" para quem vive fora desse contexto: ela vive mergulhada no universo religioso, com sua lógica e suas verdades, que têm o poder de resolver os problemas da vida: ela manda fluidificar cinco litros de água (Amarílis, s/d, p. 41), fala de "bom médium que só atrai bons elementos" (Amarílis, s/d, p.41), participa das sessões de limpeza psíquica, acredita que os espíritos que avassalaram Luísa podem cangar nela, e bate as mãos com vigor no peito chamando seu nome para afastar os maus elementos.

É evidente que, se cada personagem for considerada como estranha, ao final nenhuma delas será estranha de fato, pois a categoria da "alteridade" opera sempre em oposição a uma identidade do sujeito que funciona como "modelo" ou "norma". E, como vimos, neste conto a categoria da normalidade se dissolve. Nesse sentido, é interessante notar como Orlanda Amarílis - cuja preocupação é retratar as mulheres cabo-verdianas ou exiladas, abandonadas na solidão e ao seu destino - acaba esfumando a rígida oposição entre essas duas categorias para apresentar uma gama variada de sujeitos diferentes co-habitando num espaço rizomático, plural, sincrético, sem fechar nenhum sujeito dentro de um rótulo definitivo. Sob esse aspecto, parece-nos redutivo aprisionar essas personagens dentro da categoria do "estranho", porque muitos desses estranhamentos integram o cotidiano da cultura popular, no dia-a-dia. Basta pensarmos nos rituais cotidianos de fluidificar a água, pedir proteção aos santos e aos espíritos dos mortos, ou, voltando-nos uma vez mais para o contexto brasileiro, as práticas da Umbanda e das diferentes vertentes religiosas que, cada vez mais, criam raízes no solo das práticas culturais brasileiras.

O que pretendemos destacar é que por detrás dessas aparentes estranhezas existe uma concepção do mundo que se sustenta a partir de uma lógica própria, baseada em práticas e convicções pontuais. Por conta disso, acreditamos que a(s) alteridade(s) presente(s) neste conto - assim como aquelas de outros contos pertencentes ao mesmo contexto - pertence $(\mathrm{m})$ ao universo popular e cotidiano tanto africano como latino-americano. Sem dúvida, o ponto de vista de quem vive num contexto alheio a esse universo vai diferenciar-se dessa nossa aproximação. Contudo, parece-nos muito delicado aproximar-se deste mundo com o olhar voltado apenas para o próprio contexto; como chamar Luísa de "louca", se ela vive uma realidade que no conto é chamada "de histeria" (Amarílis, s/d, p. 44), onde os vivos têm que se submeter, às vezes, às vontades dos mortos, que, através dos espíritos, tomam conta de suas vidas? Como chamá-la de "deslocada" se o seu corpo é receptáculo de outra entidade e, por conseguinte, ela se torna dupla, sem meios de controlar esse outro eu que se impõe sobre ela?

Tzvetan Todorov se debruçou sobre narrativas como estas com o objetivo de encontrar a chave que abra, para elas, a porta de entrada no gênero da literatura fantástica. O trabalho do teórico é minucioso, pois o autor chega a delinear quatro subgêneros dentro do gênero do fantástico, definido em geral como 
a hesitação comum ao leitor e à personagem, que devem decidir se o que percebem depende ou não da 'realidade', tal qual existe na opinião comum. No fim da história, o leitor, quando não a personagem, toma contudo uma decisão, opta por uma ou outra solução, saindo desse modo do fantástico.” (Todorov, 2003, p. 48).

Esses subgêneros "compreendem as obras que mantêm por muito tempo a hesitação fantástica, mas terminam enfim no maravilhoso ou no estranho"(Todorov, 2003, p. 48), e são os seguintes: o estranho puro, o fantástico estranho, o fantástico maravilhoso e o maravilhoso puro.

O gênero fantástico lida com uma narrativa que remete a questões como o duplo, a catalepsia e a volta dos mortos, as alucinações e as desordens mentais, servindo-se do magnetismo ou de outros fenômenos "ocultos" para explicar experiências que têm a ver com o rompimento da linearidade do tempo, como no caso do conto de Orlanda Amarílis. Nesse sentido, "a poética do fantástico é basicamente uma poética da incerteza" (Magalhães, 2003, p. 28), pois problematiza as categorias da verdade e do real e questiona as demarcações rígidas entre categorias como vida/morte, natural/sobrenatural, recusando esse tipo de oposições antagônicas.

No entanto, estudos mais recentes como o de Célia Magalhães retomam a questão do gênero fantástico à luz do contexto literário latino-americano, que desde a década dos anos cinquenta introduz no campo da teoria literária o conceito do realismo mágico ou realismo maravilhoso para se referir-se à "estratégia da escrita pós-colonial na América Latina” (Magalhães, 2003, p.17) ${ }^{6}$. Nessa perspectiva, sem anteciparmos o que será abordado na conclusão deste ensaio, podemos dizer que esse viés de leitura nos parece mais adequado ao contexto africano, já que o realismo mágico é definido como "um tipo de matériaprima narrativa derivada essencialmente da sociedade camponesa valendo-se, de forma sofisticada, do mundo mítico camponês ou mesmo tribal" (Jamerson apud Magalhães, 2003, p. 40) para sustentar o universo ficcional apresentado. Além disso, o realismo mágico "cria espaço para que as diversidades possam interagir, deixando de ser hegemônico e centralizador", que é o que ocorre no conto analisado, onde cada personagem contém elementos de diversidade e de "aparente loucura", sem deixar de relacionar-se entre elas e ter seu espaço na narrativa, e representa um "modo adequado para explorar - e transgredir - fronteiras, sejam elas ontológicas, políticas, geográficas ou genéricas” (Magalhães, 2003, p. 43).

A sensação de estranhamento que experimentamos ao ler o conto decorre do fato de que algo nele agride nossa sensibilidade semântica, quando relacionada à linguagem escrita. A intranquilidade da linguagem na qual estamos imersos como leitores nos provoca, pois essa realidade é estranhamente familiar é a da linguagem oral. E como toda pessoa passa pela experiência da oralidade (pelo menos na infância), algumas de suas características ficam gravadas como algo conhecido. Encontramos no conto palavras como "histeria", "delírio", "loucura", "avassalamento" no que diz respeito às personagens, conceitos estes que remetem à ideia de precariedade, fragilidade, instabilidade e doença, apontando para um universo de loucos. ${ }^{7}$

Para Homi Bhabha (1998, p. 29), o estranhamento dessas personagens representa o paradigma da condição colonial e pós-colonial. Para Célia Magalhães, no já citado trabalho sobre os monstros, essas personagens se inscrevem no processo de representação do universo africano como sendo um universo do 
realismo maravilhoso, cujos textos "se situam no interstício de uma diversidade de mundos em que a magia - ou o maravilhoso - é introduzida no mundo real como se fora algo natural, apresentando metamorfoses e dissoluções como fatos comuns" (2003, p. 17). Nesse sentido, o realismo mágico se torna uma estratégia de oposição ao racionalismo inerente ao pós-Iluminismo e ao realismo literário, assim como, no contexto africano, o realismo maravilhoso contrasta a visão européia da África como sendo o continente da "alteridade" mais radical e absoluta: "assim, no realismo mágico, os fantasmas, os monstros [e os loucos] são introduzidos no plano do real sem que se rompa a relação causa/efeito da narrativa, já que esta se apresenta naturalmente descontínua” (Idem, 2003, p. 17).

Uma das perguntas recorrente nos escritores africanos versa sobre a possibilidade de a escrita literária abarcar a realidade plural do contexto africano, com suas tatuagens, suas línguas, seus ritos, seus provérbios e suas sabedorias ancestrais, hoje confrontada com o mundo globalizado. Nessa direção, o escritor moçambicano Ungulani Ba Ka Khosa (2000, p.284) confessa essa preocupação ao dizer que

minhas leituras tiveram sempre o intuito de encontrar mecanismos técnicos que pudessem transferir toda a realidade mágica que envolve a memória popular à escrita. Tarefa difícil, pois a memória popular consubstancia-se numa língua sem tradição de escrita. E eu queria entrar nesse mundo com a língua do "outro"; uma língua à partida incapaz de absorver todas as nuances que a tradição oral contém

e conclui dizendo:

me apercebi que os latino-americanos já vinham conquistando o mundo desde os anos $60 \mathrm{com}$ a sua realidade mágica. Foi aí que aprendi que não devíamos ter complexos com o mundo, de certa forma para-anormal, que nos rodeia; e que esse mundo, tal como se fazia no meu país, não devia ser reduzido a meros clichês (obscurantista, supersticioso, crendeiro...). [...] Foi nesse mundo multifacetado que é a América Latina que encontrei o caminho para dar vazão à nossa mágica realidade africana.

Essas considerações do escritor moçambicano demonstram como a inserção de figuras como as que analisamos no conto de Orlanda Amarílis responde, por uma lado, a uma adequação da realidade plural e cambiante da cultura popular, e, por outra parte, representa uma estratégia para tentar dar conta da realidade africana. Nesse sentido, para fechar este ensaio, gostaríamos de citar um fragmento do livro de Célia Magalhães em que a autora se refere a Elleke Boehmer $^{8}$ para explicar como os escritores pós-coloniais ingleses também se inspiraram no realismo mágico

para expressar sua visão de um mundo fissurado, distorcido e transformado em incrível pelo deslocamento cultural através dos efeitos do realismo mágico, os quais combinam o sobrenatural, a lenda e a imagem derivada das culturas colonialistas para a representação das sociedades que foram invadidas, ocupadas ou 
corrompidas politicamente. A autora acrescenta que essa escrita pode funcionar como estratégia anticolonial, pois, ao dramatizar as percepções divididas das culturas pós-coloniais, abala as representações "puristas" de mundo dos tempos coloniais e, ao misturar o bizarro e o plausível indistintamente, faz mímica do apoio à fantasia e ao exagero do europeu para descrever [os mundos colonizados] (Magalhães, 2003, p. 46)

É nesse entre-lugar, espaço de tensão entre a lógica do outro, resultante do olhar colonizador, e a lógica própria, resultante da própria concepção daquilo que é "África", que o conto abordado nesse breve ensaio, junto com os outros mencionados, ganham vida, provocando susto e encantamento para quem está pronto a se deixar surpreender e encantar.

\section{NOTAS}

1. AMARILIS, Orlanda. "Luisa filha de Nica". In: Ilhéu dos pássaros. Plátano Editora.

2. Preferimos nos referir ao fenômeno do aparente desequilíbrio mental em termos de "estranheza", já que consideraremos as diferentes concepções freudianas da representação do "estranho" no ser humano.

3. ROSA, João Guimarães. "Sorôco, sua mãe, sua filha". In: Primeiras estórias. Rio de Janeiro: José Olympio, 1972, p.15-18.

4. Refiro-me, ao fazer essas considerações, às características da sociedade ocidental.

5. Vejam-se algumas das ocorrências desse movimento de abrir-efechar: "Os portões cerrar-se-iam para sempre" (p.40); "Os portões fecharam-se sem pressa" (p.40); "Nica descansava a cabeça na persiana meio aberta e escutava de olhos fechados" (p.41); "Nica abriu uma greta" (p.41); "Nem consigo abrir os olhos" (p.41); "Abre esta capela, fecha. Agora estoutra. Abre. Fecha." (p. 41); "Entra, Tatóia, entra. Vou abrir-te a porta. - Nica cerrou as persianas, trancou as vidraças [...] fechou a porta” (p. 42).

6. Decidimos trabalhar com esse conceito, mesmo sabendo que ele é hoje seriamente questionado pela teoria literária em função da visão "distorcida" que ele veicula do contexto e das realidades latinoamericanas. $\mathrm{O}$ conceito parece corresponder hoje apenas à exigências de mercado para vender o maravilhosos em livrarias européias ou norte-americanas, como observa em entrevista concedida à revista CULT (número 74, novembro 2003) o professor e crítico literário britânico John Gledson

7. Vale acrescentar o título de outro conto onde encontramos a personagem de uma mulher louca. Trata-se do conto "Os Calundus da Joana" do escritor angolano Arnaldo Santos.

8. BOEHMER, Elleke. Colonial \& Postcolonial Literature: Migrant

Metaphors. Oxford/New York: Oxford University Press, 1995. 


\section{REFERÊNCIAS BIBLIOGRÁFICAS}

AMARÍLIS, Orlanda. Luísa filha de Nica. In: Ilhéus dos pássaros. Plátano Editora, $\mathrm{s} / \mathrm{d}$.

BHABHA, Homi K. O local da cultura. Belo Horizonte: Ed. UFMG, 1999

BA KA KHOSA, Ungulani. Tradição oral, literatura e história. In: LIENHARD, Martín (coord.). A memória popular e as suas transformações. Frankfurt am Main/ Madrid: Vervuert / Iberoamericana, 2000, p. 281-286.

CARDOSO, Boaventura. Gavião veio do sul e pum!. In: O fogo da fala (exercícios de estilo). Lisboa: Edições 70, 1980.

CONHEN, Jeffrey Jerome. A cultura dos monstros: sete teses. In: SILVA, Tomaz Tadeu da (Org.). Pedagogia dos monstros: os prazeres e os perigos da confusão de fronteiras. Belo Horizonte: Autêntica Editora, 2000, p. 23-60.

COUTO, Mia. Na berma de nenhum estrada. In: Na Berma de Nenbuma Estrada e outros contos. Lisboa: Caminho, 2001.

FOUCAULT, Michel. A História da Loucura na Idade Clássica. São Paulo: Perspectiva, 1995.

FREUD, Sigmund. O Estranho. In: Uma neurose infantil: e outros trabalhos. Edição Standard das obras completas de Freud. Rio de Janeiro: Imago, 1976. V. XVII, p. 273-318.

MAGALHÃES, Célia. Os monstros e a Questão Racial na Narrativa Modernista Brasileira. Belo Horizonte: Editora UFMG, 2003.

PEREIRA, Edimilson de A. \& GOMES, Núbia Pereira de M. Os monstros somos nós. In: Flor do não esquecimento. Cultura popular e processos de transformação. Belo Horizonte: Autêntica, 2002, p.91-114.

ROSA, João Guimarães. "Sorôco, sua mãe, sua filha". In: Primeiras estórias. Rio de Janeiro: José Olympio, 1972, p.15-18.

SANTOS, Arnaldo. "Os Calundos da Joana". In: Kinaxixe e Outras Prosas. São Paulo: Ática, 1981.

TODOROV, Tzvetan. Introduçâ à literatura fantástica. São Paulo: Perspectiva, 2003. 